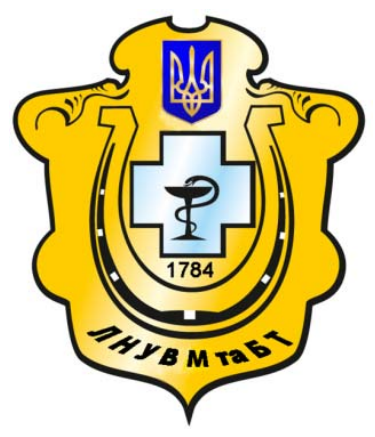

Науковий вісник Львівського національного університету ветеринарної медицини та біотехнологій імені С.3. Гжицького

Scientific Messenger of Lviv National University of Veterinary Medicine and Biotechnologies named after S.Z. Gzhytskyj

doi:10.15421/nvlvet7710

ISSN 2518-7554 print

ISSN 2518-1327 online

$\underline{\text { http://nvlvet.com.ua/ }}$

УДК 619:612.1:619:616-071:636.2

\title{
Стан гемопоезу у дійних корів за профілактики мікроелементної недостатності
}

\author{
Є.М. Колтун, В.І. Русин \\ rusin_v@ukr.net \\ Львівський національний університет ветеринарної медицини та біотехнологій імені С.3. Гжицького, \\ вул. Пекарська, 50, м. Львів, 79010, Україна
}

\begin{abstract}
Наведені результати гематологічних досліджень у дійних корів за профілактики мікроелементної недостатності неорганічними та органічними сполуками дефічитних мікроелементів. Метою наших досліджень було вивчення впливу неорганічних і органічних сполук мікроелементів на стан гемопоезу у дійних корів за профілактики мікроелементної недостатності. Матеріалом для досліджень була кров дослідних тварин, де визначали: кількість еритроцитів, лейкоцитів, тромбоцитів, гемоглобіну, величину гематокриту, середній об'єм еритроциту (MCV), середній вміст гемоглобіну в еритроциті $(\mathrm{MCH})$, середню концентрацію гемоглобіну в еритроциті (МСНС). Дані показники визначали на автоматичному гематологічному аналізаторі типу «Mythic 18 vet» (Швейчарія). Згідно з результатами гематологічних досліджень у клінічно хворих тварин встановлено олігохромемію, зниження величини гематокриту на фоні достатньої кількості еритроцитів, щзо сприяло зменшенню МСH та МCV, а також зростанню МСНС. Дані зміни гемопоезу вказують на розвиток гіпохромноі мікрочитарної анемії. Застосування клінічно хворим дійним кором в складі кормів основного рачіону органічних та неорганічних сполук дефіцитних мікроелементів сприяло нормалізації гемопоезу. Кращий терапевтичний ефект встановлено у тварин другої дослідної групи, яким згодовували хелатні сполуки дефіцитних мікроелементів у вигляді метіонатів та лізинатів. По закінченні досліду в крові тварин другої дослідної групи встановлено вірогідне збільшення вмісту гемоглобіну, величини гематокриту, МCH та MCV, а також зниження МСНC, шуо вказує на відновлення гемопоезу.

Ключові слова: дійні корови, мікроелементна недостатність, гемопоез, олігохромемія, гіпохромна мікроцитарна анемія, профілактика, халатні сполуки мікроелементів.
\end{abstract}

\section{Состояние гемопоэза в дойных коров при профилактике микроэлементной недостаточности}

\author{
Е.М. Колтун, В.И. Русин \\ rusin_v@ukr.net

\begin{abstract}
Львовский наџиональный университет ветеринарной медицины и биотехнологий имени С.3. Гжицкого,
\end{abstract} \\ ул. Пекарская, 50, г. Львов,79010, Украина
}

\begin{abstract}
Приведенны результаты гематологических исследований в дойных коров при профилактике микроэлементной недостаточности неорганическими и органическими соединениями дефицитных микроэлементов. Целью наших исследований было изучение влияния неорганических и органических соединений микроэлементов на состояние гемопоэза в дойных коров при профилактике микроэлементной недостаточности. Материалом для исследований была кровь подопытных животных, где определяли: количество эритрочитов, лейкочитов, тромбочитов, гемоглобина, величину гематокрита, средний объем эритроцита (MCV), среднее содержание гемоглобина в эритроичте (МСH), среднюю кониентрацию гемоглобина в эритроиите (МСНС). Данные показатели определяли на автоматическом гематологическом анализаторе типа «Mуthic 18 vet» (Швейиария). Согласно результатам гематологических исследований в клинически больных животных установлено олигохромемию, снижение величины гематокрита на фоне достаточного количества эритрочитов, что способствовало
\end{abstract}

Citation:

Koltun, Y.M., Rusyn, V.I. (2017). State of hemopoesis in dairy cows for the prophylaxis of microelements insufficiency. Scientific Messenger LNUVMBT named after S.Z. Gzhytskyj, 19(77), 41-44. 
уменьшению МСН и МCV, а также росту МСНС. Данные изменения гемопоэза указывают на развитие гипохромной микрочуитарной анемии. Применение клинически больным дойным коровам в составе кормов основного рациона неорганических и органических соединений дефицитных микроэлементов способствовало нормализации гемопоеза. Лучиий терапевтический эффект установлен у животных второй опытной группы, которым скармливали хелатные соединения дефицитных микроэлементов в виде метионатов и лизинатов. По окончании опыта в крови животных второй опьтной группь установлено достоверное увеличение содержания гемоглобина, величины гематокрита, МСН и МСV, а также снижение МСНС, что указывает на восстановление гемопоэза.

Ключевые слова: дойные коровы, микроэлементная недостаточность, гемопоэз, олигохромемия, гипохромная микроциитарная анемия, профилактика, хелатные соединения микроэлементов.

\title{
State of hemopoesis in dairy cows for the prophylaxis of microelements insufficiency
}

\author{
Y.M. Koltun, V.I. Rusyn \\ rusin_v@ukr.net \\ Lviv National University of Veterinary Medicine and Biotechnologies named after S.Z. Gzhytskyj, \\ Pekarska Str., 50, Lviv, 79010, Ukraine
}

\begin{abstract}
These results of hematological studies in dairy cows for the prophylaxis microelements insufficiency by inorganic and organic compounds of scarce micronutrients. The purpose of our research was to investigate the impact of inorganic and organic compounds of trace elements on the state of hemopoesis in dairy cows for the prophylaxis microelement insufficiency. The material for the research was the blood of experimental animals, where was determined: the number of erythrocytes, white blood cells, platelets, hemoglobin, the value of hematocrit, mean corpuscular volume (MCV), the average content of hemoglobin in erythrocyte (ICSU). The given indicators were determined on an automatic hematology analyzer type «Mythic 18 vet» (Switzerland). According to the results of hematological studies in clinically sick animals it was set oligochromemia, decrease in hematocrit values against the background of a sufficient number of erythrocytes, that helped to reduce the MCH and MCV, and also ICSU growth. These changes of hemopoesis indicate the development of hypochromic microcytaric anemia. Application of basic diet of organic and inorganic compounds of scarce microelements in the composition of feed to clinically sick dairy cows promoted the normalization of hemopoesis. It was established a better therapeutic effect in animals of second experimental group, which were fed with chelated compound of scarce microelements in the form of methionates and lysinates. At the end of the experiment, in the blood of animals of the second experimental group, was set up probable increase in a hemoglobin content, hematocrit values, MCH ma MCV, and also decrease of ICSU, indicating a recovery of hemopoesis.
\end{abstract}

Key words: dairy cows, trace elements, deficiency, hemopoesis, oligochromemia, hypochromic microcytaric anemia, prevention, chelate compounds of trace elements.

\section{Вступ}

Однією із важливих умов збереження здоров'я та забезпечення високої продуктивності тварин є нормована годівля за поживністю і мінерально-вітамінним складом. Особливу увагу приділяють забезпеченню тварин біотичними мікроелементами, оскільки вони відіграють важливу роль у обміні речовин і забезпечують життєдіяльність організму (Beattic and Avenell, 1992; Boikiv et al., 2001; Klitsenko et al., 2001; Gutyj et al., 2016). Дефіцит або дисбаланс мікроелементів в організмі тварин призводять до розвитку гіпомікроелементозів. Останні зустрічаються в окремих біогеохімічних зонах і провінціях України, грунти, водні джерела і рослини яких дефіцитні за вмістом рухомих форм деяких біотичних мікроелементів (Sudakov et al., 1995; Doletskyi, 2007).

Часто в господарствах для забезпечення тварин мікроелементами використовують їх неорганічні солі, проте вони не дають бажаного ефекту у зв'язку з їхньою низькою біодоступністю, у великих дозах токсичністю, а також утворенням нерозчинних комплексів (Hryhorieva et al., 1998). Враховуючи вищенаведене, актуальним залишається питання розробки ефективних способів забезпечення тварин дефіцитними мікроелементами за їх нестачі в навколишньому середовищі. Одним із таких способів профілактики мікроелементозів є застосування хелатів мікроелементів, які являють собою сполуки двовалентних металів 3 амінокислотами (Kuznetsov, 1991). Дані сполуки легко проникають через стінку кишечнику, завдяки чому їх засвоюваність становить 95-100\% (Genseh, 1991; Melnychenko and Herasymenko, 1994).

Рядом досліджень (Markiv, 1999; Olson, 1999; Kravtsiv et al., 2008; Slivinska, 2008; Bereza et al., 2010) встановлено позитивний вплив на обмін речовин i продуктивність тварин при згодовуванні різним за своїм складом хелатних комплексів мікроелементів на основі однієї амінокислоти. Проте науково обгрунтованих даних щодо застосування дійним коровам хелатного комплексу, до складу якого входили б дві незамінні амінокислоти, не виявлено.

Враховуючи вищесказане, метою наших досліджень було вивчення впливу неорганічних і органічних сполук мікроелементів на стан гемоцитопоезу в дійних корів за профілактики мікроелементної недостатності.

\section{Матеріал та методи досліджень}

Робота виконувалась на базі ПАФ «Нефедівське» Кам'янець-Подільського району Хмельницької області. Об'єктом досліджень були дійні корови чорнорябої породи, віком 4-6 років та добовим надоєм 16- 
18 л молока. Утримання тварин у господарстві прив'язне, годівля триразова, згідно з кормовим раціоном, з урахуванням маси тіла тварин, напряму продуктивності та добового надою.

Матеріалом для досліджень була кров дослідних тварин $(\mathrm{n}=16)$, де визначали: кількість еритроцитів, лейкоцитів, тромбоцитів, гемоглобіну, величину гематокриту, середній об'єм еритроциту (MCV), середній вміст гемоглобіну в еритроциті (MCH), середню концентрацію гемоглобіну в еритроциті (МСHC). Дані показники визначали на автоматичному гематологічному аналізаторі типу «Mythic 18 vet» (Швейцарія).

3 метою вивчення впливу застосування дефіцитних сполук мікроелементів на гемопоез у дійних корів нами було сформовано дві дослідні групи тварин, по 8 голів у кожній. При цьому дійним коровам першої дослідної групи разом з кормами основного раціону згодовували суміш неорганічних сполук мікроелементів у вигляді їх солей (мг/100 кг маси тіла): $\mathrm{CuSO}_{4}$ $50, \mathrm{CoSO}_{4}-5, \mathrm{ZnSO}_{4}-120$. Тваринам другої дослідної групи згодовували суміш метіонатів і лізинатів мікроелементів у такому співвідношенні компонентів (мг/100 кг маси тіла): CuMet - 15, CuLis - 15, CoMet 1 , CoLis -1 , ZnMet -35 , ZnLis - 35. Згодовування суміші сполук дефіцитних мікроелементів проводилось шляхом змішування їх з комбікормом, один раз в день, протягом 60 днів. Оцінку результатів досліджень проводили на початку та в кінці досліду.

\section{Результати та їх обговорення}

Згідно $з$ даними попередніх досліджень (Koltun and Rusyn, 2016), у дійних корів діагностували субклінічну та клінічну форми остеодистрофії на фоні низького вмісту в крові Купруму, Кобальту та Цинку. При цьому, у клінічно хворих тварин відмічали: в'ялість, зниження та спотворення апетиту, тьмяність i скуйовдженість волосяного покриву, енофтальм, анемічність видимих слизових оболонок, часткову депігментацію волосяного покриву у вигляді так званих «окулярів», зниження тургору шкіри, іiі потовщеність та сухість, зниження кількості жуйних періодів та гіпотонію передшлунків, а також зниження молочної продуктивності.

Згідно з результатами гематологічних досліджень (табл.) на початку досліду у клінічно хворих дійних корів дослідних груп встановлено олігохромемію та зниження величини гематокриту на фоні достатньої кількості еритроцитів, що сприяло зменшенню $\mathrm{MCH}$ та MCV, а також зростанню МCHC. Дані зміни гемопоезу вказують на розвиток у дійних корів гіпохромної мікроцитарної анемії.

Кількість лейкоцитів та тромбоцитів в крові тварин дослідних груп перебувала в межах фізіологічних коливань (табл.).

Деякі показники гемоцитопоезу у дійних корів, $\mathbf{n}=8$

\begin{tabular}{|c|c|c|c|c|c|}
\hline \multirow{2}{*}{ Показники } & \multirow{2}{*}{$\begin{array}{l}\text { Біометричні } \\
\text { показники }\end{array}$} & \multicolumn{2}{|c|}{ Початок досліду } & \multicolumn{2}{|c|}{ Кінець досліду } \\
\hline & & I дослідна & II дослідна & I дослідна & II дослідна \\
\hline \multirow{2}{*}{ Еритроцити, Т/л } & Lim & $4,4-8,6$ & $4,3-9,1$ & $5,5-7,6$ & $6,0-7,5$ \\
\hline & $\mathrm{M} \pm \mathrm{m}$ & $6,5 \pm 0,48$ & $6,6 \pm 0,59$ & $6,7 \pm 0,25$ & $6,9 \pm 0,16$ \\
\hline \multirow{2}{*}{ Гемоглобін, г/л } & Lim & $62,0-109,0$ & $59,0-120,0$ & $92,0-109,0$ & $105,0-122,0$ \\
\hline & $\mathrm{M} \pm \mathrm{m}$ & $90,1 \pm 6,84$ & $89,4 \pm 7,20$ & $100,4 \pm 2,12$ & $112,9 \pm 2,18 * * / x^{x x}$ \\
\hline \multirow{2}{*}{ Гематокрит, \% } & Lim & $16,0-35,4$ & $15,3-36,3$ & $26,2-35,1$ & $33,8-39,1$ \\
\hline & $\mathrm{M} \pm \mathrm{m}$ & $25,2 \pm 1,92$ & $25,7 \pm 2,44$ & $31,1 \pm 1,08^{*}$ & $35,9 \pm 0,92 * * /^{x x}$ \\
\hline \multirow[b]{2}{*}{ МCH, пг } & Lim & $12,4-15,3$ & $12,2-15,6$ & $14,3-16,4$ & $15,3-17,4$ \\
\hline & $\mathrm{M} \pm \mathrm{m}$ & $13,9 \pm 0,28$ & $13,8 \pm 0,36$ & $15,2 \pm 0,33^{* *}$ & $16,3 \pm 0,22 * * * / x$ \\
\hline \multirow{2}{*}{$\mathrm{MCV}$, фл } & Lim & $35,8-41,0$ & $35,3-41,7$ & $44,3-48,1$ & $49,3-58,1$ \\
\hline & $\mathrm{M} \pm \mathrm{m}$ & $38,6 \pm 0,66$ & $39,0 \pm 0,70$ & $46,9 \pm 0,44 * * *$ & $52,4 \pm 0,96 * * * /{ }^{\mathrm{xxx}}$ \\
\hline \multirow{2}{*}{$\mathrm{MCHC,} \mathrm{г/л}$} & Lim & $316-379$ & $304-386$ & $303-351$ & $295,0-320,0$ \\
\hline & $\mathrm{M} \pm \mathrm{m}$ & $349,5 \pm 8,96$ & $352,6 \pm 9,84$ & $323,5 \pm 6,85^{*}$ & $314,6 \pm 4,63 * *$ \\
\hline \multirow{2}{*}{ Лейкоцити, Г/л } & Lim & $6,8-11,9$ & $7,6-12,6$ & $6,0-14,8$ & $6,6-14,9$ \\
\hline & $\mathrm{M} \pm \mathrm{m}$ & $9,8 \pm 0,60$ & $10,4 \pm 0,56$ & $9,2 \pm 0,89$ & $10,1 \pm 1,06$ \\
\hline \multirow{2}{*}{ Тромбоцити, Г/л } & Lim & $210-495$ & $182-510$ & $236-513$ & $248-439$ \\
\hline & $\mathrm{M} \pm \mathrm{m}$ & $346 \pm 52,01$ & $320,9 \pm 55,93$ & $358,6 \pm 29,23$ & $346,0 \pm 24,02$ \\
\hline
\end{tabular}

Примітка: * $-P<0,05 ;{ }^{* *}-P<0,01 ; * * *-P<0,001-$ порівняно з початком досліду; ${ }^{x}-P<0,05$; $^{x x}-P<0,01 ;{ }^{x x x}-$ $P<0,001-$ порівняно з І дослідною групою

Кількість еритроцитів в крові тварин дослідних груп по закінченні досліду була в межах фізіологічних коливань і вірогідно не відрізнялась між групами (табл.).

Застосування сполук дефіцитних мікроелементів позитивно вплинуло на вміст гемоглобіну в крові тварин дослідних груп, проте 3 деякою відмінністю між ними (табл.). Так, по закінченні досліду у корів першої дослідної групи вміст гемоглобіну перебував у межах фізіологічних коливань, проте відносно початку експерименту встановлено лише тенденцію до його зростання. У тварин другої дослідної групи встановлено, що вміст гемоглобіну був вищим на 26,3\% (P < 0,01) відносно початку досліду та на $12,5 \%$ ( $<0,01)$ порівняно з першою дослідною групою.

Встановлено також позитивний вплив мікроелементної підгодівлі і на величину гематокриту, яка по закінченні досліду зросла у крові дійних корів першої дослідної групи на 23,4\% (P < 0,05), другої - на 39,7\% $(\mathrm{P}<0,01)$. При цьому в крові тварин другої дослідної групи даний показник був вищим на $15,4 \%(\mathrm{P}<0,01)$ порівняно з першою дослідною групою (табл.). 
Вірогідне збільшення вмісту гемоглобіну в крові клінічно хворих тварин пов'язано із застосуванням в складі мікроелементної суміші сполук Купруму, який посилює мобілізацію депонованого Феруму до кісткового мозку, забезпечуючи включення його у структуру гему. Натомість зростання величини гематокриту, пов'язано із збільшенням в крові об'єму еритроцитів відносно іï загального об'єму, що свідчить про позитивний вплив сполук Кобальту на процеси дозрівання еритроцитів на ранніх стадіях розвитку в еритробластах червоного кісткового мозку.

Зростання в крові дослідних тварин вмісту гемоглобіну та величини гематокриту відповідним чином позначилось на показниках індексів червоної крові. Так, у крові дійних корів першої та другої дослідних груп по закінченні досліду встановлено зростання МСН відповідно на 9,4 (P < 0,01) і 18,1\% (P<0,001), MCV - на 21,5 $(\mathrm{P}<0,001)$ i $34,4 \%(\mathrm{P}<0,001)$, а також зниження $\mathrm{MCHC}$ на 7,4 (P < 0,05) і 10,8\% (P < 0,01) порівняно 3 початком досліду. При цьому у тварин другої дослідної групи МСН та MCV були вищими відповідно на 7,2 (Р $<0,05)$ та $11,7 \%(\mathrm{P}<0,001)$ порівняно $з$ першою дослідною групою. Одержані нами результати досліджень вказують на нормалізацію процесів дозрівання еритроцитів, збільшення їхнього об'єму в циркулюючій крові та насичення їх гемоглобіном.

Підсумовуючи результати гематологічних досліджень, необхідно відзначити, що застосування хелатних сполук біогенних металів $\epsilon$ альтернативним та ефективним засобом корекції обмінних процесів за профілактики мікроелементної недостатності у тварин.

\section{Висновки}

1. У клінічно хворих дійних корів встановлено ознаки порушення гемопоезу, характерні для гіпохромної мікроцитарної анемії.

2. Згодовування дійним коровам у складі основного раціону неорганічних і органічних сполук дефіцитних мікроелементів сприяло нормалізації показників гемопоезу.

3. Кращий терапевтичний ефект відносно нормалізації показників гемопоезу встановлено у тварин другої дослідної групи, яким застосовували комплекс хелатних сполук дефіцитних мікроелементів у вигляді метіонатів та лізинатів.

Перспективи подальших досліджень. Перспективними є подальші дослідження щодо впливу комплексу хелатних сполук мікроелементів на окисно-відновні процеси в організмі та продуктивність дійних корів в умовах профілактики мікроелементної недостатності.

\section{Бібліографічні посилання}

Beattic, J.H., Avenell, J.H. (1992). Trace element nutrition and bone metabolism. Nutr. Res. Cambriolge. 5, 167-188.

Boikiv, D.P., Svystun, Yu.D., Fartushok, N.V. (2001). Mikroelementy: dosiahnennia i perspektyvy. Eksperymentalna klinichna fiziolohiia ta biokhimiia. 2, 124-128 (in Ukrainian).

Klitsenko, H.T., Kulyk, M.F., Kosenko, M.V. (2001). Mineralne zhyvlennia tvaryn. K. (in Ukrainian).
Sudakov, M.O., Bereza, V.I., Pohurskyi I.H. (1995). Mikroelementozy u silskohospodarskykh tvaryn na Ukraini. Mater. nauk. - vyrob. konf. «Aktualni pytannia veterynarnoi medytsyny». K., 124-125 (in Ukrainian).

Doletskyi, S. (2007). Stan mineralnoho obminu v orhanizmi laktuiuchykh koriv zakhidnoi heokhimichnoi zony Ukrainy. Veterynarna medytsyna Ukrainy. 8, 2528 (in Ukrainian).

Hryhorieva, H.S., Kyrychok, L.M., Konakhovych, N.F. (1998). Kompleksoutvorennia yak sposib pidvyshchennia neshkidlyvosti spoluk mikroelementiv. Sovremennyie problemy toksykolohii. 1, 21-23 (in Ukrainian).

Kuznetsov, S.H. (1991). Biolohicheskaia dostupnost mineralnykh veshchestv dlia zhivotnykh iz kormodobavok y khimicheskikh soiedinienii. Selskokhoziaistvennaia biolohiia. 6, 150-160 (in Russian).

Genseh, A.L. (1991). Amino acid Chelates: their mechanism of action and key aspects of preparations. Journal Appel. Nutrit. 31 (24), 36.

Gutyj, B.V., Hufriy, D.F., Hunchak, V.M., Khariv, I.I., Levkivska, N.D., Huberuk, V.O. (2016). The influence of metisevit and metifen on the intensity of lipid per oxidation in the blood of bulls on nitrate load. Scientific Messenger LNUVMBT named after S.Z. Gzhytskyj. 18, 3(70), 67-70 doi: http://dx.doi.org/10.15421/nvlvet7015

Melnychenko, O.M., Herasymenko, V.H. (1994). Oderzhannia khelatokompleksnykh spoluk biohennykh metaliv z metoiu vykorystannia yikh u tvarynnytstvi. Nauk.-prak. konf. «Vcheni Bilotserkivskoho derzhavnoho silskohospodarskoho instytutu». Tezy dop. Bila Tserkva, 154 (in Ukrainian).

Markiv, A.M. (1999). Vplyv khelativ deiakykh mikroelementiv na fiziolohichnyi stan sukhostiinykh koriv ta yikh teliat: avtoref. dys. na zdobuttia nauk. stupenia kand. veter. nauk. Lviv, 19 (in Ukrainian).

Olson, P.A. Brink, D.R., Hickok, D.T. (1999). Effects of supplementation of organic and inorganic combinations of copper, cobalt, manganese, and zinc above nutrient requirement levels onpostpartum two-year-old cows. Journal of Animal Science. 77 (3), 522-532.

Kravtsiv, R.Yo., Usachenko, L.M., Kovaliv, L.M. (2008). Vplyv defitsytnykh mikroelementiv $\mathrm{u}$ formi mineralnykh solei abo khelatnykh spoluk (metionativ) na orhanizm tvaryn ta yikhni produktyvni yakosti. Nauk. visnyk LNUVM ta BT im. S.Z. Gzhytskoho. Lviv, 10 (4), 119-126 (in Ukrainian).

Slivinska, L. (2008). Vmist kobaltu i midi v krovi ta stan erytrotsytopoezu za anemii u Zakhidnomu rehioni Ukrainy pry zastosuvanni preparatu "MIKROLAKT". Silskyi hospodar. 11-12, 31-34 (in Ukrainian).

Bereza, V.I., Holopura, S.I., Tsvilikhovskyi, M.I. (2010). Zastosuvannia tvarynam khelatnykh spoluk biohennykh mikroelementiv z profilaktychnoiu i likuvalnoiu metoiu. Zb. nauk. prats KHDZA. Kharkiv. 22 (2), 1, 211-215 (in Ukrainian).

Koltun, Ye.M., Rusyn, V.I. (2016). Kliniko-biokhimichnyi status diinykh koriv PAF «Nefedivske» KamyanetsPodilskoho raionu Khmelnytskoi oblasti. Nauk. visnyk LNUVM ta BT im. S.Z. Gzhytskoho. Lviv. 18, 3 (71), 37-40 (in Ukrainian).

Стаття надійшла до редакиії 20.03.2017 